\title{
Book Review: The Correspondence of Catharine Macaulay by Karen Green (ed.), Oxford University Press, 2019, 328 pages. ISBN: 978-0190934453
}

\author{
Alan M. S. J. Coffee \\ King's College London, UK \\ alan.coffee@kcl.ac.uk
}

Keyword: Catharine Macaulay; History of Women in Philosophy; Republicanism; Neo-republicanism; 18th century; Radicalism; American Revolution

This is a very welcome collection. It brings together for the first time all of Catharine Macaulay's available correspondence. The prominence of those with whom Macaulay engaged is such that the volume takes on the appearance of a who's who of the significant figures of radical and revolutionary Britain, American, and France in the second half of the 18th century. This gives the book a wide potential appeal. It should be of interest, not just to the growing number of Macaulay scholars, but to those studying the history of women in philosophy and politics; radicalism and dissent in the 18th century; the American and French Revolutions; as well as Enlightenment thought more broadly. Macaulay is also one of the central figures in what is now known as the neo-republican political tradition, on account of both her own voluminous writings and the company that she kept (many of whom are either represented as corespondents themselves or are discussed in the letters). This book, therefore, represents an invaluable resource for anyone writing in the field of republican political philosophy.

Widely celebrated and highly influential in her time, Macaulay's thought fell into almost complete obscurity after her death in 1791, not to be revived until the late 20th century. There has, however, been a resurgence of interest in her work in recent years. This volume arrived on the scene just a few months before Green's intellectual biography, Catharine Macaulay's Republican Enlightenment (Routledge 2020) and ahead of Wendy Gunther Canada's forthcoming, A Friend of Liberty: Catharine Macaulay and the Enlightened Republic (Oxford University Press). No one has done more than either Green or Gunther Canada in recent years to further our understanding of Macaulay's thought and its significance and so this is truly a rich time for the study of Macaulay. This collection also has the distinction of being the only currently published edition of any of Macaulay's work (as far as I am aware). It is greatly to be hoped that this landmark publication will spur on interest in the reissue of her extensive body of substantive texts - such as her Letters on Education, her several volumes of historical writing, or her replies to Edmund Burke - as scholarly editions. 
The collection contains 217 letters between Macaulay and 56 different correspondents. Several of these were previously available, if often difficult for scholars to access, having been spread across various locations in archives or included as part of the works of her correspondents (such as Benjamin Franklin, David Hume, Mercy Otis Warren, or George Washington). The majority of the letters, however, come from a collection housed in the Gilder Lehrman Institute of American History in New York that came about following the sale by one of Macaulay's heirs in 1992. The volume as a whole comes with a comprehensive and insightful overall introduction by Green herself to Macaulay's life and the contours of her thought, and each separate correspondent is given a short, dedicated and very helpful introduction of their own that places both the writer and the subject matter in context. Not included in this volume are the Letters on Education (which represent a fictionalised treatise), the replies to Burke (which were written as tracts), or Macaulay's Short Sketch for a Democratical form of Government, written stylistically in the form of a letter to the exiled leader of Corsica, Pasquale Paoli (and was presented to him), although these are all referred to in the correspondence. Included in the appendix, however, is a Petition Drawn up for the Use of the City of London, on the rights and privileges of the citizens, presented to the throne in 1769.

Taken together, these letters provide us with a fascinating glimpse into the intellectual and radical life of 18th-century England and America. They give us an insight into some of the connections between its leading figures and the themes and events that preoccupied them, as well as highlighting the central role that Macaulay herself played within these circles. Amongst the Americans, for example, Macaulay is received with warmth and enthusiasm by an array of founding fathers, signatories to the constitution, and pamphleteers, including Benjamin Franklin, Benjamin Rush, Samuel Adams, and James Otis, as well as both current and future presidents, in George Washington and John Adams. Equally significantly, we see how Macaulay engages extensively and in some depth on political matters with leading women of the revolution, such as Abigail Adams, Sarah Prince Gil, and Mercy Otis Warren. Warren was, in fact, the longest-standing correspondent that we have available for Macaulay. Their letters begin in 1773 and continue to just a few weeks before Macaulay's death in 1791, taking in the build-up to independence, the early struggles of the republic, European international politics, and the French Revolution.

As Green notes in her introduction to the collection, with the exception of those with her daughter, Macaulay's surviving letters are mostly written in a rather public style that tends not to reveal her deepest or most candid and personal reflections. There are several exceptions to this, however. Macaulay wrote a heated letter to Ralph Griffiths, the proprietor and editor of the intellectual journal, the Monthly Review, in which a poor, and apparently rather slipshod, review of her Letters on Education had appeared. Macaulay does not hold back and takes the review apart point by point, often humorously but also with great precision. The reviewer had suggested that Macaulay was a rather better historian than philosopher (something with which both philosophers and historians of the 21st century are likely to disagree). She confesses that her education had, indeed, been lacking, while setting the reviewer straight on his understanding of Plato and Aristotle. She reminds him that, unlike most women, he had not experienced 'the task of cultivating [his] own mind and the pursuing and overtaking science in an irregular chase without a guide' and so should 'pity us poor unlearned women' (290). Later, and equally sarcastically but with a good deal of self-awareness and, perhaps, feeling, Macaulay refers to her own fading reputation, acknowledging that the laurels that once graced [her] brow are now in their wane' (291). She then laments the current state of historical and political analysis, which directly contradicts the republican theories that had animated her own work. 
The letters also provide us with an insight into the extent that Macaulay's longstanding illness and frail physical condition affected her over the course of the last decade and a half of her life from the late 1770s, inhibiting her ability to write and hampering her ability to travel. She did still travel to both France and America, though her trip to France in 1777 was cut short because of her health. Macaulay gives a very positive account of the 'decent rational system of social life' that she found in Paris (79). She contrasts the 'servile disposition' of the English towards their monarch with the general ambivalence, and often outright hostility, towards the royal family in France. Indeed, the French that she met paid her what she says they took to be their two highest compliments, first that she was 'a hater of kings' and only second, that she was a literary genius (80). Regarding attitudes towards her own countrymen, she reports a deep and widespread hatred and jealousy of the English, not only in France but universally across the continent of Europe. Although she is making a republican and political point, she probably does the affections of the English by the French no favours in her description of the food she encountered, which ultimately caused her to cut short her stay. 'Their meat is carrion', she says, 'their poultry and even their game insipid, and their cookery most detestable. They have no good spices to season their meats with, and they use them too sparingly; their made dishes are a collection of gravy drawn from bad meat', concluding that 'thus the stomach is loaded with everything baneful to it without the assistance of warm spices to help digestion' (80-1). Her assessment, of course, is as likely to have been a reflection of the weakness of Macaulay's own constitution as much as of the food shortages and failed harvests that were common in pre-revolutionary France (though I am with her on the importance of spices).

The letters also give us a very rich theoretical supplement to Macaulay's published work. A particular gem is her reply to the lawyer and activist Capel Lofft. The occasion is the report given to Macaulay by Lofft of Richard Price's famous address to the Revolution Society in 1789. Price and Macaulay mixed in the same radical and dissenting circles, and although no correspondence between them is available, Price's name crops up regularly across the material from the early 1770 s as being of a very similar mind to Macaulay. In the structure of their moral and political philosophy, the two are very close. Both build their political ideals around a central republican ideal of freedom as independence from arbitrary power that entails a capacity for and willingness to exercise a rational virtue that is underpinned by a theological commitment to a benevolent God. This basic structure is worked out in a different genre by Macaulay and Price respectively but nevertheless gives their positions a remarkably similar shape and application. It was, therefore, intriguing to read Macaulay write to Lofft, 'I need not tell you how intensely my sentiments agree with those of the excellent Dr Price and I admire his courage' (285). While she may have only meant to praise the spirit of rather than philosophy behind his sentiments, I am very glad to have read this firsthand account of her attitude to Price's work. In the same letter, Macaulay - a lifelong Anglican - disavows the standard belief in a triune God, telling Lofft that 'I never was a Trinitarian but I acknowledge to you that I Worship Jesus Christ as the Lord of all the human race and as a Being deserving of all the honors which God can confer on any of his creatures', suggesting that she held a unitarian position that seems to lie further along the spectrum than Price's Arianism but perhaps stopping short of the Socinianism of Joseph Priestley (whose name appears less often in this collection and whose republican philosophy diverges somewhat from that of Price and Macaulay).

Macaulay's correspondence with George Washington also makes fascinating theoretical reading (as well as including such personal touches as his sounding her out for a recommendation for an English steward who might oversee a 250 acre farm of his). Washington writes, for example, of the considerable good fortune that the Americans had in establishing their new state successfully and of the fragility of its condition. In her reply, Macaulay reiterates her commitment to the general position that institutional design must work to prevent and 
negate corrupting motives within the government. She rolls back on the recommendation that she made in her Sketch for Signore Paoli (and reiterated in a letter to Benjamin Rush in 1769) that the rotation of offices would be sufficient, in light of the corruption that continued in England at that time and of the French approach following the revolution, accepting now that it would be safer to prevent currently serving legislators to hold any civil office during their term. She also questions Washington on the division of the legislature into an upper and lower house, fearing that this might lead to a creeping back of monarchy as the upper house gains in prestige and power, leading to an inequality of power 'which never ought to take place in a Society of free men' (278).

As well as the correspondence, the volume comes with an excellent introduction that almost any reader, no matter how familiar with Macaulay's life and work, will be grateful for. No one is better placed than Green to write such a guide. There is, however, one aspect of Macaulay's thought that Green does not mention. This is Macaulay's commitment, not just to a republican politics, which is clear, but specifically to what is now referred to as the neo-Roman republican ideal of freedom as independence. This is rather a shame because one of the greatest services this volume does for those writing in this tradition today is to show very clearly the central place that Macaulay has in the history of republican thought and the enormous influence she had. Macaulay's neo-republicanism is something of a blind spot for Green, who explicitly disavows this interpretation of Macaulay's philosophy in several articles. This is not the place to rehearse those arguments, but anyone interested might refer to an exchange between Green and me (and Sandrine Bergès and others) on this subject in the Australasian Philosophical Review (volume 3, 2020). In short, Green believes interpreting Macaulay through a republican philosophical lens to be a retrospective imposition on historical women based on contemporary male perspectives grounded in the work of Philip Pettit. This is, in my view, a misnomer.

The historical conception that Macaulay shares with Price and many others in this volume, differs in several respects from the contemporary ideal. While this historical position clearly had patriarchal roots, it was a living and contested political position that was constantly evolving. Not only did a great many women write in this tradition - not only Macaulay but also Mary Wollstonecraft, Anna Laetitia Barbauld, Mary Hays, Olympe de Gouges, Sophie de Grouchy, and Marie-Jeanne Roland, amongst many others - but together they can be seen to constitute a theoretically innovative and distinctive strand of republican writing. That women philosophers were writing to each other, discussing politics and abstract ideals in a republican context comes through very strongly in this volume. A particularly striking example is in the extensive correspondence between Macaulay and Warren. In one letter, Warren identifies the tension between the imperative in a fragile, fledgling state 'of a strong Federal Government' that can hold together the union, and the task of preserving the liberty for which its people have struggled and made sacrifices (163). Macaulay replies that there is no inherent tension between liberty and the fact of government power, so long as it protects rather than ruins liberty (in other words, so long as its power is non-arbitrary). If Macaulay does not quite address the practical issue that Warren raises, her answer is nevertheless impeccably republican.

In summary, I am very glad to have read Macaulay's correspondence. The depth of scholarship and editorship that has gone into the compiling, transcribing, and interpreting of the material in the volume is very impressive and meticulously executed. The collection makes a wonderful contribution to the study of women in the history of philosophical and political thought. More than that, in trying political times today, this is a book that should, in Macaulay's words, inspire 'the minds of every zealous friend to equal liberty' (296).

\section{Competing Interests}

The author has no competing interests to declare. 
How to cite this article: Coffee, Alan M. S. J. 2020. "Book Review: The Correspondence of Catharine Macaulay by Karen Green (ed.), Oxford University Press, 2019, 328 pages. ISBN: 9780190934453." Redescriptions: Political Thought, Conceptual History and Feminist Theory 23(1): 79-83. DOl: https://doi.org/10.33134/rds.332

Submitted: 22 June $2020 \quad$ Accepted: 22 June $2020 \quad$ Published: 13 July 2020

Copyright: (c) 2020 The Author(s). This is an open-access article distributed under the terms of the Creative Commons Attribution 4.0 International License (CC-BY 4.0), which permits unrestricted use, distribution, and reproduction in any medium, provided the original author and source are credited. See http://creativecommons.org/licenses/by/4.0/.

Redescriptions: Political Thought, Conceptual History and

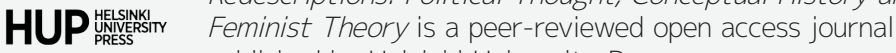

